\title{
Application of Break Even Point Analysis on Some Agricultural Products. The Case of Kahta (Adiyaman) District
}

\author{
İsmail UKAV \\ Department of Accounting and Tax, Kahta Vacational School Adiyaman University, Adiyaman, Turkey
}

\begin{abstract}
The most important goal of the business is to make a profit. It is expected that in the businesses, the production factors will be used effectively and the profit target will be achieved. Profit is also the most important indicator in agricultural production enterprises. To achieve this goal, profit planning is required. One of the most appropriate methods used in profit planning is break even point analysis. With the help of break even point analysis, important information is obtained about the level of production at which the enterprise passes to profit, how the changes in production affect the profits and the amount of production required to achieve a certain profit target. In this study, fifteen of the agricultural products produced in Kahta district of Adiyaman were subjected to break even point analysis in order to determine the level of transition to profit. The statistical data of Kahta District Directorate of Agriculture and Forestry in 2018 were used in this study. Break-even point was calculated for each product by analyzing the data. According to the results of the analysis, the products that reached the highest yield / break-even point ratio were onion, melon and tomato.
\end{abstract}

Keywords: Break even point analysis, agricultural production, cost, Kahta

DOI: $10.7176 / \mathrm{JESD} / 10-16-10$

Publication date: August $31^{\text {st }} 2019$

\section{Introduction}

When undertaking any job, it is often compared to the effort and resources to be spent for that job and the benefit to be earned from that job. The purpose of this comparison is to find out at which production level the income from production and the expenses to resources (production factors) are equalized and to determine at which point this work is profitable. This comparison, which applies to all activities, is especially important in economic life. Because economic units need to make a profit, at least to cover their expenses, in order to survive. Therefore, profit planning is as important as planning activities for successful management. In order to analyze or estimate the profit or loss, it is often necessary to compare income and expense. At the production level where income and expenditure are equal, the profit of the enterprise is zero because the enterprise can only cover its expenses. This level of production is called the break-even point (the point of transition to profit or the point of zero profit) (Ceylan and Korkmaz, 2010). In the break even point analysis, the relationship between the foreseen incomes, costs and expenses and profits of the company at different production levels is revealed. In break-even point analysis, costs are divided into fixed and variable costs. The fact that operating costs can be allocated as fixed and variable in the short term makes the analysis to be used easily. The profit of the enterprise from sales is realized in different ways at different production levels, and a small change in sales may cause a greater change in the profit of the enterprise. This is due to the fact that some production costs are realized more or less than the change in production quantity. Break-even point analysis is very useful in these aspects.

Besides the usefulness of break-even point analysis, it has benefits. These; the level of business volume required to achieve the profit target of the enterprise, costs (fixed and variable) and the effects of changes in unit sales price on the profit and the profit point of the enterprise and the total profit, the most profitable product types to be selected and the production composition accordingly, the calculation of unit costs determining the low selling price. In addition, break even point analysis can guide business management in the following areas. Considering the risk level in new investments, determining the minimum production capacity, determining the sales volume that would justify such growth in case the company increases its production capacity, determining the required business volume to reach the profit target of the enterprise, the production, price and investment policies to be followed by the enterprise. to help the management to make decisions.

Despite these advantages of break even point analysis, some assumptions should also be considered. These can be explained as follows: Business costs; fixed and variable costs. The fixed costs remain the same at various production levels. Unit sales prices do not change. The overall price level is stable. Variable costs change, decrease or increase at the same rate as production quantities. In other words, variable expenditure per unit remains the same. There are no changes in the policies that the business follows. There is a complete synchronization between sales and production. Every manufactured goods or services are sold. The productivity of production factors remains the same. The business produces one kind of goods or services. If the enterprise produces various goods, the composition of production does not change.

Break even point analysis can be made to prevent criticism based on realistic assumptions. However, as implementation difficulties and complexity will increase, sound results may not be achieved. As a result, break- 
even point analysis can be used as the first approach to pricing, investment and financing decisions (Aydin et al., 2010a).

Agricultural production process is quite different from other sectors. In this context, there are many factors that cause risk and uncertainty in the agricultural sector. Some of those are uncertainties in natural conditions, uncertainties in prices, changes in technology and changes in producers' status. In addition to these, the facts that agricultural lands have a multi-part structure, low price and income elasticity of agricultural products, and the number of intermediaries in marketing of products are among the characteristics of the sector. All of this reveals the importance of break even point analysis, which is defined as the production volume, in the determination of the production volume in the agricultural sector, after which all the expenses are covered and the enterprise passes to profit.

The lack of a break even point analysis of agricultural products in Kahta district increases the importance of the study. Kahta, which is the largest district of Adiyaman, one of the provinces of Southeastern Anatolia Region, is a settlement located on 38-17 east longitude and 37-45 north latitude and 750 meters above sea level. The district, which reaches a height of 2000 meters in the north, is surrounded by mountains and has a surface area of 1490 $\mathrm{km} 2$. It is located $33 \mathrm{~km}$ east of Adiyaman. The northern part of the district consists of mountainous areas and the southern part consists of plain areas. The highest point in the north is Mount Nemrut $(2,206 \mathrm{~m})$. As we move southward from the mountainous areas, we first pass to the plateau areas and then to the wide plains. Kahta has a land structure that starts at the southern slopes of the Antitoros Mountains and descends to the south and extends towards the Harran Plain. Since the region is located between the Eastern and Southeastern Anatolia Regions, it has the characteristics of the climate of these regions. In addition, it also has some of the climatic characteristics of the Mediterranean Region. Therefore, the flora of the region reflects the characteristics of these three regions (Adiyaman Governorate, 2019).

$70 \%$ of the regional economy is based on agriculture. Approximately $60 \%$ of employed people work in agriculture. $35 \%$ of the land is composed of agricultural land; $81 \%$ of these lands are dry farming and $19 \%$ are irrigated farming. $84.2 \%$ of the field products consist of cereals, $10.4 \%$ of industrial plants, $4.4 \%$ of legumes, and the rest consists of oil seeds and tuber plants (2017 Briefing Year, 2018). In this scope, field products such as pistachio, almond, walnut, pomegranate, olive, tomato, pepper, cucumber, eggplant, corn, watermelon, and melon are produced as well as wheat, barley, red lentils, chickpeas, cotton, tobacco, nectarine, dried garlic.

In this study, the break-even point analysis of fifteen agricultural products, which are determined to be intensively produced in Kahta district of Adiyaman, is aimed to determine the production level of the products and to make recommendations to the producers in this context.

\section{Material and Method}

In this study, data of Kahta District Directorate of Agriculture and Forestry, which is affiliated to the Ministry of Agriculture and Forestry, were used. These data consist of yield, unit prices, production expenses, gross and net income. The data were obtained through surveys and observations applied by the authorities to producers (Table 1). In break-even point analysis, cost separation is of great importance. Costs were determined separately for each product examined. In this analysis, costs are divided into two groups:

Table 1. Data on Some Agricultural Products Grown in Kahta District (2018)

\begin{tabular}{|c|c|c|c|c|c|}
\hline Products & $\begin{array}{l}\text { Estimated unit } \\
\text { price } \mathrm{TL} / \mathrm{Kg}\end{array}$ & Yield (Kg/da) & $\begin{array}{l}\text { Production costs } \\
(\mathrm{TL} / \mathrm{da})\end{array}$ & $\begin{array}{l}\text { Gross income } \\
(\mathrm{TL} / \mathrm{da})\end{array}$ & $\begin{array}{l}\text { Net income } \\
(\mathrm{TL} / \mathrm{da})\end{array}$ \\
\hline Barley & 0.97 & 450 & 334.84 & 524 & 189.16 \\
\hline Wheat & 1.04 & 450 & 330.42 & 555.5 & 225.08 \\
\hline Red Lentil & 2.20 & 170 & 364.19 & 422 & 57.81 \\
\hline Chickpeas & 2.85 & 220 & 343.19 & 627 & 283.81 \\
\hline Tobacco & 12.00 & 90 & 890.98 & 1080 & 189.02 \\
\hline Pepper & 1.50 & 1.633 & 1386.84 & 2449.5 & 1062.66 \\
\hline Tomatoes & 1.60 & 2.500 & 1413.09 & 4000 & 2586.91 \\
\hline Cucumber & 1.20 & 2.600 & 1704.99 & 3120 & 1415.01 \\
\hline Eggplant & 1.35 & 1.825 & 1189.97 & 2463.75 & 1273.78 \\
\hline Onion & 2.40 & 1.500 & 1136.05 & 3600 & 2463.95 \\
\hline Groin Corn & 1.15 & 900 & 813.83 & 1035 & 221.17 \\
\hline Watermelon & 0.56 & 3.000 & 1178.94 & 1680 & 501.06 \\
\hline Melon & 1.30 & 1.800 & 926.20 & 2275 & 1348.80 \\
\hline Gum pumpkin & 1.08 & 1.650 & 1125.70 & 1782 & 656.30 \\
\hline Garlic & 2.54 & 850 & 1204.30 & 2159 & 954.70 \\
\hline
\end{tabular}

Source: Kahta District Directorate of Agriculture and Forestry, 2018.

1) Fix costs: Costs that do not depend on the quantity of production, regardless of the volume of production. 
These are generally rent, interest, insurance, business investment costs, taxes, administrative fees. Although these expenses are made for production activities, they are, in other words, independent of production regardless of production levels. Whether there is production or not; whether the amount of production increases or decreases, they always remain the same. These costs are compulsory costs that are not directly related to the increase or decrease of production.

2) Variable costs: It consists of increasing or decreasing cost elements in proportion to the production volume. Inputs, used in production process, direct labor costs and overheads constitute this group. Variable costs vary in parallel to changes in production. If the amount of production increases, the raw material and material requirement used in production increases. Similarly, increasing production causes an increase in the number of workers who will work directly in the realization of this production.

Therefore, while analyzing the data, fixed and variable costs were determined separately for each product. In this study, it was observed that fixed costs for the analyzed agricultural products consist of rent and interest costs. Variable costs consisted of the following elements: plowing the field, fertilizer price and fertilizing labor, seed cost, sowing and seed closing labor, hoeing, irrigation cost and labor, agricultural drug cost and labor, manual harvesting, price of harvesting with combine harvester, warehousing and market transport costs and so on. Graphical and algebraic methods can be used in break-even point analysis.

Finding break-even point (BEP) by graphical method:

Fixed costs (FC), variable costs (VC) and their total costs (TC) are determined using the available data of business. In addition, the total revenue (TR), multiplied by the production / sales quantity and the unit sales price (qxp), is calculated and transferred to the graphical environment. Since fixed costs (FC) do not change at every point of production, they are drawn parallel to the production / sales axis (Figure 1). Since total costs (TC) are the sum of fixed (FC) and variable (VC) costs, they are drawn starting from the beginning of fixed costs (FC). Since total revenue (TR) varies depending on the production / sales quantity, it starts from the origin and gradually increases. The point where total revenue (TR) and total cost (TC) overlap is the break-even point. Prior to this point, the business is in the loss zone as it has not yet met the costs. After the break-even point, the business makes profit.

FC : Fix cost

VC: Variable cost

TC: total cost $(\mathrm{FC}+\mathrm{VC})$

TR: total revenue (qxp)

Q: production quantity

P: price

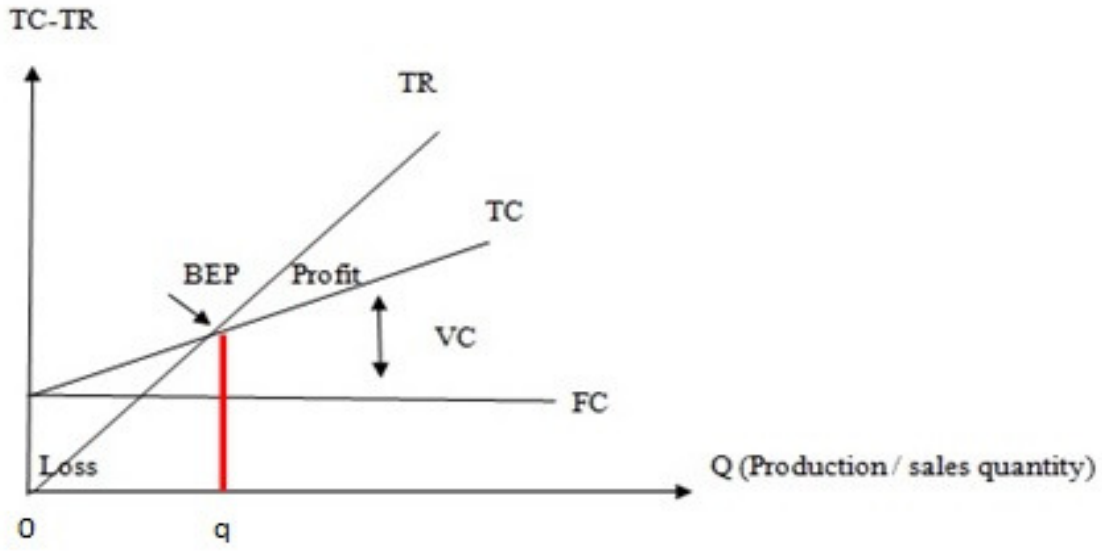

Figure 1. Breakeven point analysis chart

Considering the assumptions on which the linear break-even analysis is based, assuming that the production amount of the variable expenses and the sales revenue is the linear function of the sales amount will enable the break-even point to be calculated.

Finding the break-even point by Mathematical (Algebraic) Method:

Under the assumptions of break-even point analysis, it is easier to calculate the transition point to profit when it is assumed that an entity's variable expenses are the linear functions of the production amount and the sales proceeds are the linear functions of the sales quantity. The level of transition to profit will be the level of production where total expenses and total revenues are equal. There is no profit or loss at this point. In this study, algebraic method was used for break-even point analysis. At this method

TFC: Total Fix cost

TVC: Total Variable cost 
TC : Total cost (TFC+TVC)

AVC: Average Variable cost $\mathrm{AVC}=(\mathrm{TFC} / \mathrm{q})$ have been calculated separately.

Calculation of break-even point as quantity: Considering that the expenses of the enterprise will be equal to their income at the point of break-even point (transition to profit); it is possible to write $F+(V x Q)=P x Q$. In the equality; $\mathrm{F}=$ Fixed expenses, $\mathrm{V}=$ Variable expense per unit, $\mathrm{P}=$ Unit sales price, $\mathrm{Q}$ indicates the quantity to be produced and sold for break-even point. The quantity required to be produced and sold in order to reach the breakeven point can be written as follows.

Production quantity at the break-even point (Q): $B E P=T F C /(P-A V C)$

Calculation of Break-even Point as Sales Value: The break-even point can be calculated in units or in sales value. The following equation can be used when calculating the break-even point as sales amount:

Production quantity at break-even point $(\mathrm{S}): B E P=\frac{T F C}{1-\frac{A V C}{P}}$

The contribution margin was also calculated. The contribution margin is the difference between sales and variable costs.

Contribution margin: P-AVC

Businesses do not aim to make break-even point production level but aim to make more profits by producing more. This is the case when the profit should be at a targeted level rather than zero (Aydin et al., 2010b). The formula used in relation to the target profit is as follows.

Target profit point (quantity): TFC+Profit/ (P-AVC)

\section{Results and Discussions}

Wheat, barley, red lentils, chickpeas, tobacco, nectarine, dried garlic, grain corn, tomato, pepper, cucumber, eggplant, corn, watermelon and melon that are produced in Kahta District were analyzed.

According to the results of the research, it was determined that the yield of agricultural products, which are grown in Kahta and subject to the research, district is sufficient to cover the total costs. The highest yield / breakeven ratio of the products subject to analysis were determined to be onion, melon and tomato respectively (Table 2 ). The break-even point among these products is well below the average dry onion yield, due to the fact that the variable costs per unit are low and the sales price is high. Production above the break-even point in other products is a result of high yields. Among the examined products, the yield to break-even point of red lentils was quite low (12). One of the most important reasons for this is the high average variable costs in red lentils. While the yields of red lentils, barley, wheat, tobacco and chickpeas are proportionally close to the break-even point, the fact that other crops are far from the break-even point shows that they can have a significant advantage for the profitability of the businesses.

Table 2. Break-even points of some important agricultural products grown in Kahta

\begin{tabular}{|l|r|c|c|}
\hline Products & Yield (kg/da) & BEP $(\mathrm{kg} / \mathrm{da})$ & Yield/BEP (\%) \\
\hline Onion & 1.500 & 66 & 2173 \\
\hline Melon & 1.800 & 112 & 1507 \\
\hline Tomatoes & 2.500 & 160 & 1463 \\
\hline Garlic & 850 & 93 & 714 \\
\hline Eggplant & 1.825 & 211 & 744 \\
\hline Cucumber & 2.600 & 308 & 607 \\
\hline Pepper & 1.600 & 231 & 405 \\
\hline Gum Pumpkin & 1.650 & 327 & 368 \\
\hline Chickpeas & 220 & 47 & 297 \\
\hline Watermelon & 3.000 & 755 & 181 \\
\hline Tobacco & 90 & 32 & 180 \\
\hline Wheat & 450 & 161 & 148 \\
\hline Grain corn & 900 & 363 & 137 \\
\hline Barley & 450 & 190 & 12 \\
\hline Red Lentil & 170 & 152 & \\
\hline
\end{tabular}

The positive contribution rates of all analyzed agricultural products indicate that the sales prices of the products are at a level that can meet the fixed costs. The low contribution margin rate is related to the sales price of the product and the variable costs per unit (Polat, 2012). As in the case of red lentils, the high share of the average variable costs in the sales price leads to a decrease in the contribution margin rate. When the sales prices of the examined products are compared with the variable costs per unit, the share of the average variable cost within the sales price is highest with $77 \%$ in red lentils, $73 \%$ in tobacco and $64 \%$ in grain corn; dry onion (28\%), tomato $(31 \%)$ and melon $(36 \%)$ were determined to be the lowest (Table 3 ). 
Table 3. Average variable costs and contribution margin rates of some important agricultural products grown in Kahta

\begin{tabular}{|l|r|c|c|c|c|}
\hline Products & $\begin{array}{c}\text { Sale Price } \\
(\mathrm{TL} / \mathrm{kg})(1)\end{array}$ & $\begin{array}{c}\text { AVC } \\
(\mathrm{TL} / \mathrm{kg})(2)\end{array}$ & $\begin{array}{c}\text { AVC ratio to sale } \\
\text { price (\%) }(2 / 1)\end{array}$ & $\begin{array}{c}\text { Contribution } \\
\text { margin } \\
(1-2) \\
(3)\end{array}$ & $\begin{array}{c}\text { Contribution } \\
\text { margin }(\%) \\
(3 / 1)\end{array}$ \\
\hline Barley & 0.97 & 0.575 & 59 & 0.40 & 41 \\
\hline Wheat & 1.04 & 0.566 & 54 & 0.47 & 46 \\
\hline Red Lentil & 2.20 & 1.687 & 77 & 0.51 & 23 \\
\hline Chickpeas & 2.85 & 1.213 & 43 & 1.64 & 57 \\
\hline Tobacco & 12.00 & 8.762 & 73 & 3.24 & 27 \\
\hline Pepper & 1.50 & 0.741 & 49 & 0.76 & 51 \\
\hline Tomatoes & 1.60 & 0.494 & 31 & 1.11 & 69 \\
\hline Cucumber & 1.20 & 0.582 & 49 & 0.62 & 51 \\
\hline Eggplant & 1.35 & 0.561 & 42 & 0.79 & 58 \\
\hline Onion & 2.40 & 0.681 & 28 & 1.72 & 72 \\
\hline Grain corn & 1.15 & 0.739 & 64 & 0.41 & 36 \\
\hline Watermelon & 0.56 & 0.338 & 60 & 0.22 & 40 \\
\hline Melon & 1.30 & 0.462 & 36 & 0.84 & 64 \\
\hline Gum pumpkin & 1.08 & 0.583 & 54 & 0.50 & 46 \\
\hline Garlic & 2.54 & 1.279 & 50 & 1.26 & 50 \\
\hline
\end{tabular}

Onion, tomato and melon take the first place among the products in terms of selling price to meet the fixed costs. While the sales price of dry onion covers the fixed costs by $72 \%$, this rate is determined as $69 \%$ in tomatoes and $65 \%$ in melons (Table 3 ).

Sales amount (volume) is the production value that is obtained when the production amount reaches the level required for the businesses to make a profit. The sales volumes of products other than red lentils, tobacco and corn were determined to be profitable (Table 4). Red lentil sales volume has to increase by $496 \%$ in order to meet the total cost. Similarly, the increase in sales volume by $103 \%$ in tobacco and by $89 \%$ in corn is necessary to cover the total cost.

Table 4. Sales volumes of products

\begin{tabular}{|l|r|r|r|}
\hline \multirow{2}{*}{ Products } & \multicolumn{2}{|c|}{ Sales Volume (TL/da) } & \multirow{2}{*}{ Rate \% } \\
\cline { 2 - 3 } & \multicolumn{2}{|c|}{ Sold (1) } & \multicolumn{2}{c|}{ BEP (2) } & 3 \\
\hline Barley & 189.16 & 184.30 & 26 \\
\hline Wheat & 225.08 & 167.44 & 496 \\
\hline Red Lentil & 57.81 & 344.40 & 53 \\
\hline Chickpeas & 283.81 & 133.95 & 63 \\
\hline Tobacco & 189.02 & 384.00 & 90 \\
\hline Pepper & 1062.66 & 346.50 & 74 \\
\hline Tomatoes & 2586.91 & 256.00 & 78 \\
\hline Cucumber & 1415.01 & 369.60 & 94 \\
\hline Eggplant & 1273.78 & 284.85 & 89 \\
\hline Onion & 2463.95 & 158.40 & 91 \\
\hline Grain corn & 221.17 & 417.45 & 89 \\
\hline Watermelon & 501.06 & 422.80 & 46 \\
\hline Melon & 1348.80 & 145.60 & \\
\hline Gum pumpkin & 656.30 & 353.16 & \\
\hline Garlic & 954.70 & 236.22 & \\
\hline
\end{tabular}

In order to cover the total costs, the sales volume must be reached as it follows: grain corn 417.45 TL / da, tobacco $384 \mathrm{TL} / \mathrm{da}$ and red lentil $344.40 \mathrm{TL} / \mathrm{da}$ (Table 4).

Businesses do not want to make break even production, but want to make more profit by producing more. For this purpose, the analysis was also made in relation to the target profit level. As it is known, the break-even point gives the production level when the profit is zero. Here, it is possible to determine how much production is required for the producers to reach this profit target by targeting a certain amount of profit. In this study, a profit target of $100 \mathrm{TL} /$ da was calculated for all products. For example, if barley production is targeted at $100 \mathrm{TL} / \mathrm{da}$;

targeted profit production level $=($ Profit $+\mathrm{TFC}) /(\mathrm{P}-\mathrm{AVC})=440 \mathrm{~kg} / \mathrm{da}$. In short, the production amount should be $440 \mathrm{~kg} / \mathrm{da}$ in order to reach the targeted profit of $100 \mathrm{TL}$ in the calculation using barley-related fixed cost, price and average variable cost data. Table 5 shows the amounts that other products examined should be 
produced in order to reach 100 TL profit. Accordingly, in order to reach the targeted profit level, the least product should be tobacco $(62 \mathrm{~kg} / \mathrm{da})$; the most commonly produced product should be watermelon $(1210 \mathrm{~kg} / \mathrm{da})$.

Table 5. Production amount required in case of profit target of $100 \mathrm{TL}$

\begin{tabular}{|l|r|}
\hline Products & Amount to be produced (kg/da) \\
\hline Tobacco & 62 \\
\hline Chickpeas & 108 \\
\hline Onion & 124 \\
\hline Garlic & 173 \\
\hline Melon & 231 \\
\hline Tomatoes & 250 \\
\hline Eggplant & 338 \\
\hline Red Lentil & 348 \\
\hline Pepper & 363 \\
\hline Wheat & 370 \\
\hline Barley & 440 \\
\hline Cucumber & 470 \\
\hline Gum Pumpkin & 527 \\
\hline Grain Corn & 607 \\
\hline Watermelon & 1210 \\
\hline
\end{tabular}

\section{Conclusion}

The question of at which production point the costs of the factors of production used by the producers in a production process can be determined by the method of break-even point analysis. This method, which is quite easy and understandable, can also be applied to the products produced in the agricultural sector. In this study, break-even point analysis of wheat, barley, red lentils, chickpeas, tobacco, nectarine, dried garlic, grain corn, tomato, pepper, cucumber, eggplant, corn, watermelon and melon produced in Kahta district of Adiyaman were analyzed. According to the results of the analysis, it was determined that the productivity levels of these products can meet the costs and especially the productivity of onion, melon and tomato were high. In the onion, break-even point was realized at a low point. As a positive result, this is due to the fact that the variable costs per unit are low, whereas the onion sales price is high. In red lentils, it was determined that the break-even point was far from the other products. For producers, the fact that the yields of the products are far from break-even point is an important factor that increases profitability.

The contribution margin rates of all analyzed agricultural products were determined as positive. In this case, the sales prices of the products are sufficient to cover the fixed costs. According to this indicator onion is the most advantageous product. In addition, sales volumes of products other than red lentils, tobacco and corn were found to be profitable. In the analysis of reaching the target profit level, it was found that tobacco came first. This is due to the high unit sales price of tobacco.

As can be seen here, businesses have to make decisions to use their resources effectively and efficiently. In making these decisions, it is especially important to make profit planning. In this process, the importance of implementation of break-even point analysis emerges.

\section{References}

Adiyaman Governorate. (2019), Accessed : 12.07.2019. Available: http://www.adiyaman.gov.tr/sehrimiz Aydın, N., Ceylan, A., Başar, M., Coşkun, M. \& Bakır, H. (2010), Financial Management, Anadolu University Publication No:1465, Eskişehir. p361.

Aydın, N., Ceylan, A., Başar, M. \& Coşkun, M. (2010), Financial Management, Detay Publication. Ankara. ISBN:978-605-5681-8-4. s614.

2017 Year Briefing, (2018), Adiyaman Governorate Provincial Directorate of Food, Agriculture and Livestock Briefing for 2017, p72.

Ceylan, A. \& Korkmaz, T. (2010), Financial Management in Business. Ekin Publication., Bursa.p679.

Kahta District Directorate of Agriculture and Forestry Statistics, (2018).

Polat, K. (2012), Breakeven Analysis in Important Products in Turkey. 10. National Agricultural Economy Congress, 5-7 September 2012. Konya/Turkey.p 567-572. 